\title{
VITAROVAT \\ Hozzászólások a \\ Kovárványcsíkok képződése a Nyírség homoktalajában c. cikkhez
}

\author{
Hozzászólások: AGROKÉMIA ÉS TALAJTAN 66 (2017) 1, 9-34 \\ DOI: $10.1556 / 0088.2017 .66 .1 .2$
}

\begin{abstract}
Ahogy a folyóirat előző füzetében megjelent cikknél jeleztük, a cikk szerzői és bírálóik véleménye több ponton eltért egymástól, melyekre a szerzők alább reagálnak.

\section{KUTI László hozzászólása}

Magyar Földtani és Geofizikai Intézet, Környezetföldtani Osztály 1143 Budapest, Stefánia út 14. kuti.laszlo@mfgi.hu
\end{abstract}

A felszínközeli laza üledékek oxidációs zónájában helyenként vöröses színủ vasfelhalmozódás található. Magyarországon ezek leginkább az eolikus üledékekre, a futóhomokra és a löszre jellemzőek, de találkoztunk velük más genetikájú, pl. folyóvízi üledékekben is.

E felhalmozódások megjelenési formájuk alapján lehetnek sávok, lencsék vagy foltok. Keletkezésük alapján lehetnek a felszínen kialakult, majd eltemetett szintek, bemosódások a felszín felől, vagy a talajvíz ingadozási zónájának a felső szintjén történő kiválások.

Annak eldöntésére, hogy az adott területen melyik fordul elö, arra az adott képződményegyüttes szedimentológiai, ásványtani és geokémiai tanulmányozása adhat megfelelő segítséget.

Ez történt a tamáspusztai homokfal esetében is.

A nyírségi felszíni, felszínközeli futóhomok a pleisztocén utolsó eljegesedési szakaszában, a Würmben alakult ki. Annak hideg száraz időszakaiban a Tisza és mellékfolyói által a megelőző interglaciálisban korábban lerakott folyóvízi homokot hozta át és halmozta buckákba a területre jellemző É-i, ÉK-i szél. Majd az így keletkezett homokbuckákat a szél még a későbbi holocénben is formázta. A jelentős mértékủ lehülés azonban a Würm glaciálisban sem volt folyamatos. A hideg száraz időszakokat nedvesebb, melegebb időszakok, interstadiálisok szakították meg, amikor megvoltak a feltételek a növényzet kialakulására, s ezáltal a talajképződésre. Majd az újabb lehülés újabb erősödő szélmozgást, az adott térszínen valamilyen mértékủ lepusztulást, és újabb homokmozgást, homoklerakódást eredményezett. Ez eltemette a felszínen korábban kialakult, s a lehülés következtében növényborítás 
nélkül maradt felszínt. A felszínen kialakult és még megmaradt talajosodott réteg ennek következményeként a felszín alá került a ráhordott homokréteg vastagsága által meghatározott mélységbe.

Kérdés, hogy ez történt-e Tamáspusztán. Az elvégzett ásványtani és geokémiai vizsgálatok erre keresték a választ. És megadták, hogy igen.

Az ásványtani vizsgálatok eredményei alapján egyértelmü, hogy az itteni kovárványos és a nem kovárványos rétegek homokfrakciója mindenben azonos ásványi összetételü, és ugyanazon homoktest része. A rétegek közti különbségek a homokszemcsék felaprózódásában, a szemcseméret csökkenésében és föleg a kötőanyag jelenlétében, annak uralkodóan limonitos összetételében vannak. A mikroszkópos vizsgálatok a kovárványos rétegben egyértelmúen utaltak a biológiai eredetủ korrózióra és feldarabolódásra.

$\mathrm{Az}$ adott kovárványos réteg felszínén bekérgeződött széleróziós nyomok találhatók. Ez egyértelmüen arra utal, hogy e réteg valamikor a felszínen volt, s ott deflációs hatásoknak volt kitéve.

A talajtani, mikrobiológiai és ásványtani vizsgálatok egyértelmüen alátámasztják, hogy a kovárványos vasfelhalmozódás felszínközeli, azaz talajtani folyamatok eredménye, csak nem a recens talajokat létrehozó folyamatoké, hanem az adott időben az adott felszínen lévő üledékeket talajosító folyamatoké. Ezek az adott időszaki felszíni képződmények az aktuális klimatikus változások következményeként kismértékben lepusztultak, majd az uralkodó szél által a területre szállított futóhomok betemette őket. Ez a folyamat egy időszakban az adott klimatikus körülmények következményeként többször ismétlödött. Hasonló előfordulások egyébként más futóhomokos területeken is előfordulnak.

\section{FÜLEKY György hozzászólása}

Szent István Egyetem, Mezőgazdaság-, és Környezettudományi Kar, Környezettudományi Intézet

2100 Gödöllő, Páter Károly u. 1. fuleky.gyorgy@mkk.szie.hu

Jelen hozzászólásomban bírálónk legfontosabb megjegyzéséhez, miszerint nem bizonyított teljesen a kovárványcsíkok pedogenetikus/biológiai eredete szeretnék hozzászólni.

A kovárványképződés tisztázásához elsődlegesen az a megfigyelés vezetett, hogy a sokszor több centiméter, illetve deciméter vastag kovárványszalagok nagy vastartalma miképpen származhatott a felette lévő vékonyabb, durva és nagy homoktartalmú rétegből. Az általánosan elfogadott elmélet szerint (BORSY, 1961, KÁDÁR, 1951, STEFANOVITS, 1953) a csapadékvíz mozgatta lefelé a felsőbb homokrétegből a vasionokat megfelelő $\mathrm{pH}$ viszonyok mellett. Ezen elmélet bár lényegét tekintve logikus, azonban nem nyert igazán bizonyítást.

A másik gondolatéberesztő megfigyelésem az volt, hogy Óbudán a Bécsi út és a Lajos utca közötti területen (1. és 2. ábra) épülő piac és más épületek alapozását megelőző régészeti vizsgálat során azt tapasztaltuk, hogy a középkori rétegre 
rárakódott eróziós hordalék eltávolítása után az ekkor kb. 4 m-es szelvény falában előbb kékes-zöld, majd fokozatosan vörösödő színủ réteg jött létre, ami nagyon hasonlított a kovárvány-rétegekhez. Ugyanekkor a megnyitott középkori felszínen az előbbivel megegyezö magasságban szintén vörös foltok, a gyökérjáratok körül vörös karikák jöttek létre (3. ábra), (sajnos a képek színei az évek során megváltoztak), a gyökérjáratokban felfelé haladó vasvegyületek szétdiffundálása következtében, és ott rögzülve hozták létre a vörös színü vas-oxihidroxid köröket. Mindkét jelenségre a magyarázat a következő lehet: a vörös színủ vaskiválások oka, hogy a területen jelenlévő egykori betemetett Duna-ág/csatorna magas Duna vízállás esetében feltöltődött vízzel, és az alsóbb rétegek vastartalmát oldva a víznyomás azután felfelé mozgatta. Az ekkor már több méter vastag, tömörödött hordalékkal borított réteg nem engedte a vas-ionokat feljebb mozogni, és így azok megrekedtek az adott magasságban, majd oxidálódva vas-oxihidroxid csapadék formájában kiváltak vörös színű vasfelhalmozódást okozva. A vasoxihidroxid kiválás jelzett folyamata egyértelmüen bizonyította az alulról történő vízmozgással bekövetkező vasfelhalmozódás lehetőségét.

Ez a jelenség vezetett egy másik esetleges kovárványképződési folyamat megfogalmazáshoz a Nyírségben. Eszerint feltételeztem, hogy a mindig jelenlévő laposokban található víz a homokdombokban felfelé diffundálva magával vihette a kioldott vasvegyületeket, melyek a felszín közelében vas-oxihidroxidként kicsapódtak. A homokdombok fokozatos kiemelkedésével pedig más- és más helyen jöhettek létre a kovárvány rétegek.

Ezek alapján tettem fel a kérdést a dolgozatban, hogy kimutatható-e a vasmozgás nyoma a kovárványrétegek feletti, illetve alatti homokban, vagyis, hogy van-e kimutatható jele a felülről történt Fe lemosódásnak, vagy az alulról történt Fe felhalmozódásnak. A kérdés, illetve a további kérdések megválaszolása során alakult ki a kovárványrétegek kialakulásának biológiai-pedogenetikai elmélete cáfolva egyúttal az alulról, illetve felülröl történő vízmozgás által történt kialakulást. Eszerint az ásványtani vizsgálatok bizonyítják:

1. a kovárványrétegek és az alattuk, illetve felettük lévő rétegek ásványi összetétele azonos, tehát nem mutatható ki a különböző időpontban szélerózióval idehordott rétegek közötti különbség.

2. a kovárványrétegek felső felületének felszíni eredetét a széleróziós koptatás nyomai bizonyítják.

3. a kovárványréteg nagyobb agyagtartalmát biológiai eredetű felaprózódásnak feltételezik, vagyis nem fogadja el az „előrajzolt” nagyobb agyag-tartalmú rétegek jelenlétét. Az „elörajzolt” nagyobb agyag-tartalmú réteg jelenléte mind az alulról, mind a felülről történő Fe mozgás során a vasfelhalmozódás helye lehetne.

4. vasmozgás a kovárványréteg feletti homokban nem volt kimutatható, ugyanakkor a kovárványréteg alatti homokrétegbe történő elmozdulás jelei voltak megfigyelhetök.

A kovárványrétegek képződésének korát illetően fontos eredményt kaptunk, miszerint a több négyzetméteres felületen lefelé történő bontás során kirajzolódott a kovárványrétegek 3D képe (lásd a megjelent dolgozatban lévő képet), ami tehát nem lapos, 2D-s jelenség, hanem egy erősen gyúrt, elasztikus formájú képződményt 
mutat, ami elsősorban a felsőbb talajszinteken mutatta ezt a formát. A Nyírségben található homokbányák falából kibukott „rögbilabda”-szerủ kovárvány képződményekkel ellentétben másutt inkább a „diszkosz” jellegű képződményekkel találkozhattunk. A gyúrt, gyürődött forma periglaciális időszakban már létrejött képződményre utal, egyúttal a képződmény „tixotróp” jellegére is, ami az amorf vasvegyületek egyik jellegzetes tulajdonsága.

Egy másik fontos vizsgálati tevékenység a vas oxidációs-redukciós folyamtokra történő utalás volt. Ezért került sor a talajszelvény humusztartalmának és egy későbbi munkánkban forróvízoldható széntartalmának, valamint a vas átalakulásában résztvevő mikroszervezetek részletes vizsgálatára. Ezek a mikroszervezetek ugyanis bizonyosan részt vettek a vaskiválás folyamatában. A vizsgálatokhoz a fenti dolgozatban közölt 2008-as minták mellett a 2007-ben és 2011-ben, valamint 2013-ban vett mintákat is felhasználtuk. Sajnos a nagy időtávlat miatt ezen vizsgálatok (1. táblázat) nem szolgáltattak bizonyítékot egyik feltételezésre sem.

\section{1. táblázat}

A mikrobiológiai és talajtani paraméterek összefüggése (r értékek)

\begin{tabular}{|c|c|c|c|c|}
\hline & $2007, \mathrm{n}=16$ & $2008, \mathrm{n}=12$ & $2011, n=8$ & $2013, n=12$ \\
\hline Gombaszám & $\begin{array}{l}\mathrm{K}_{\mathrm{A}}=0,2809(+) \\
\mathrm{H} \%=0,7215(+)\end{array}$ & $\begin{array}{c}\mathrm{pH}_{\mathrm{KCl}}=0,7006 \\
(-) \\
\mathrm{pH}_{\mathrm{H} 2 \mathrm{O}}= \\
0,3399(-) \\
\mathrm{H} \%=0,4653 \\
(+)\end{array}$ & $\begin{array}{l}\text { HWP-C = } \\
0,2541(-)\end{array}$ & $\begin{array}{c}\mathrm{pH}_{\mathrm{H} 2 \mathrm{O}}=0,3412(-) \\
\mathrm{H} \%=0,4736(+) \\
\mathrm{HWP}-\mathrm{C}=0,2725 \\
(+)\end{array}$ \\
\hline $\begin{array}{l}\text { Biomassza- } \\
\text { szén }\end{array}$ & $\begin{array}{l}\mathrm{K}_{\mathrm{A}}=0,3721(+) \\
\mathrm{H} \%=0,4457(+)\end{array}$ & - & $\begin{array}{c}\mathrm{H} \%= \\
0,4302(-)\end{array}$ & $\begin{array}{c}\mathrm{pH}_{\mathrm{H} 2 \mathrm{O}}=0,3600(+) \\
\mathrm{H} \%=0,5548(+) \\
\mathrm{Fe}_{\mathrm{ox}}=0,4360(+)\end{array}$ \\
\hline $\mathrm{CO}_{2}$ & $\begin{array}{c}\mathrm{pH}_{\mathrm{KCl}}=0,2999 \\
(-) \\
\mathrm{H} \%=0,3631(+) \\
\mathrm{pH}_{\mathrm{H} 2 \mathrm{O}}=0,4719 \\
(-)\end{array}$ & $\begin{array}{c}\mathrm{pH}_{\mathrm{H} 2 \mathrm{O}}=0,3439 \\
(-)\end{array}$ & - & $\begin{array}{c}\text { HWP-C }=0,5138 \\
(-)\end{array}$ \\
\hline Foszfatáz & & & $\begin{array}{c}\mathrm{H} \%= \\
0,5311(-)\end{array}$ & \\
\hline Összcsíraszám & & & & $\mathrm{P}=0,2172(+)$ \\
\hline
\end{tabular}

(+) pozitív, (-) negatív lineáris összefüggés

A vizsgálatok eredményeit összevetve a három kovárványképződési elmélettel nem tehettünk mást, mint közzétettük a talajtani/biológiai eredet koncepcióját, mint új kovárványképződési elméletet, nem kizárva azonban a felülről történő leszivárgó és az alulról felfelé mozgó vízzel történő vasmozgás, majd a vasvegyületek kiválásán alapuló folyamatok jelenlétét sem. 


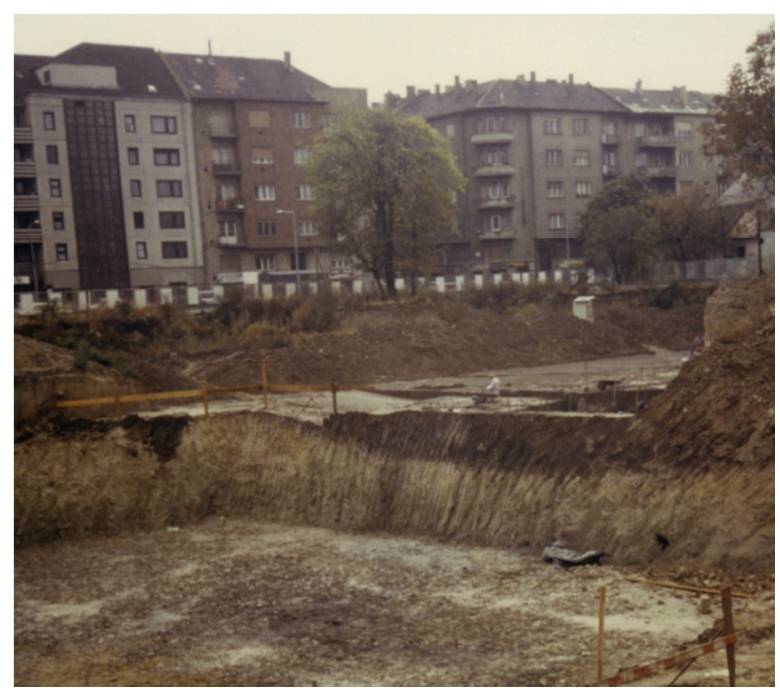

1. ábra

Ásatási helyszín Óbudán

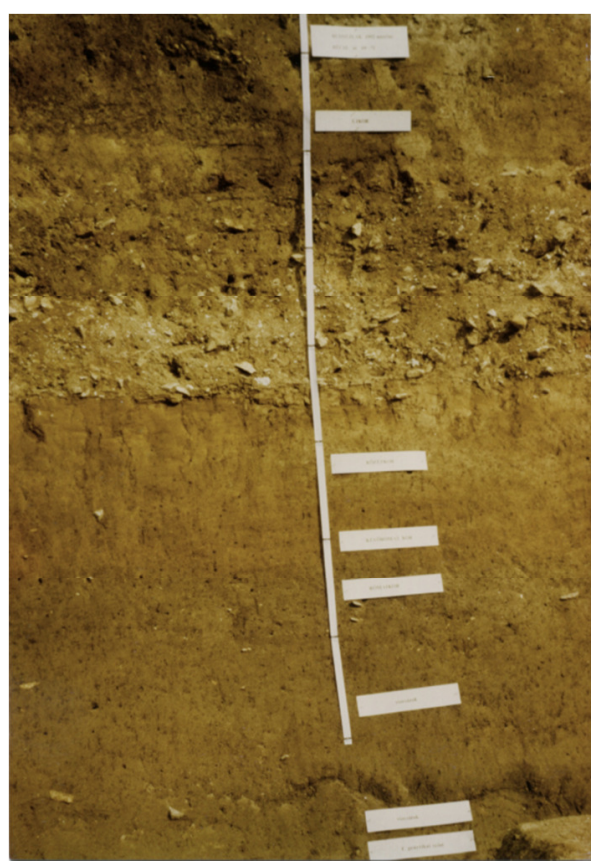

2. ábra

Óbuda üledék/talajszelvény 


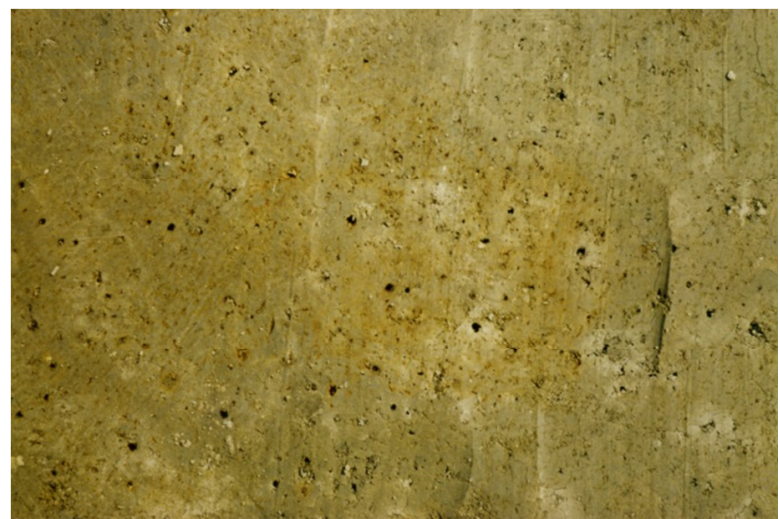

3. ábra

Vaskiválások a gyökérjáratok körül

\section{Irodalom}

BoRsy Z. 1961: A Nyírség természeti földrajza. Akadémiai Kiadó, Budapest, 227. p.

KÁDÁR L. 1951: A kovárvány probléma. Földrajzi értesítő, XXI: 17-25 Budapest STEFANOVITS P. 1953: A nyírségi kovárványos homok. Az MTA Agrártudományi Osztály Közleményei, III. 1-4, 1-11 p. 